\title{
Riñón en herradura con megacaliosis y litiasis renal en su interior
}

\author{
Boix Orri R, Buisan Rueda O, Arzoz Fabregas M, Ruiz Domínguez J, Uria González-Tova J, \\ Saladié Roig JM.
}

Servicio de Urología. Hospital Germans Trías i Pujol. Barcelona.

Actas Urol Esp. 2006;30(7):731

Presentamos el caso de un varón de 30 años sin antecedentes de interés, que a raíz de un cuadro de dolor lumbar izquierdo se practica estudio radiológico. Se objetiva; riñón en herradura con litiasis pielica en hemi-riñón izquierdo, estenosis de la unión y megacaliosis.

Se practica pieloplastia desmembrada con resolución de la obstrucción y de la litiasis.
Se muestran las imágenes de pielografía más representativas de antes y después de la intervención quirúrgica.

\section{Dr. R. Boix Orri}

Servicio de Urología. Hospital Germans Trías i Pujol Ctra. del Canyet, s/n 08916 Badalona (Barcelona) E-mail: mestreru@hotmail.com

(Trabajo recibido el 31 de agosto 2005)
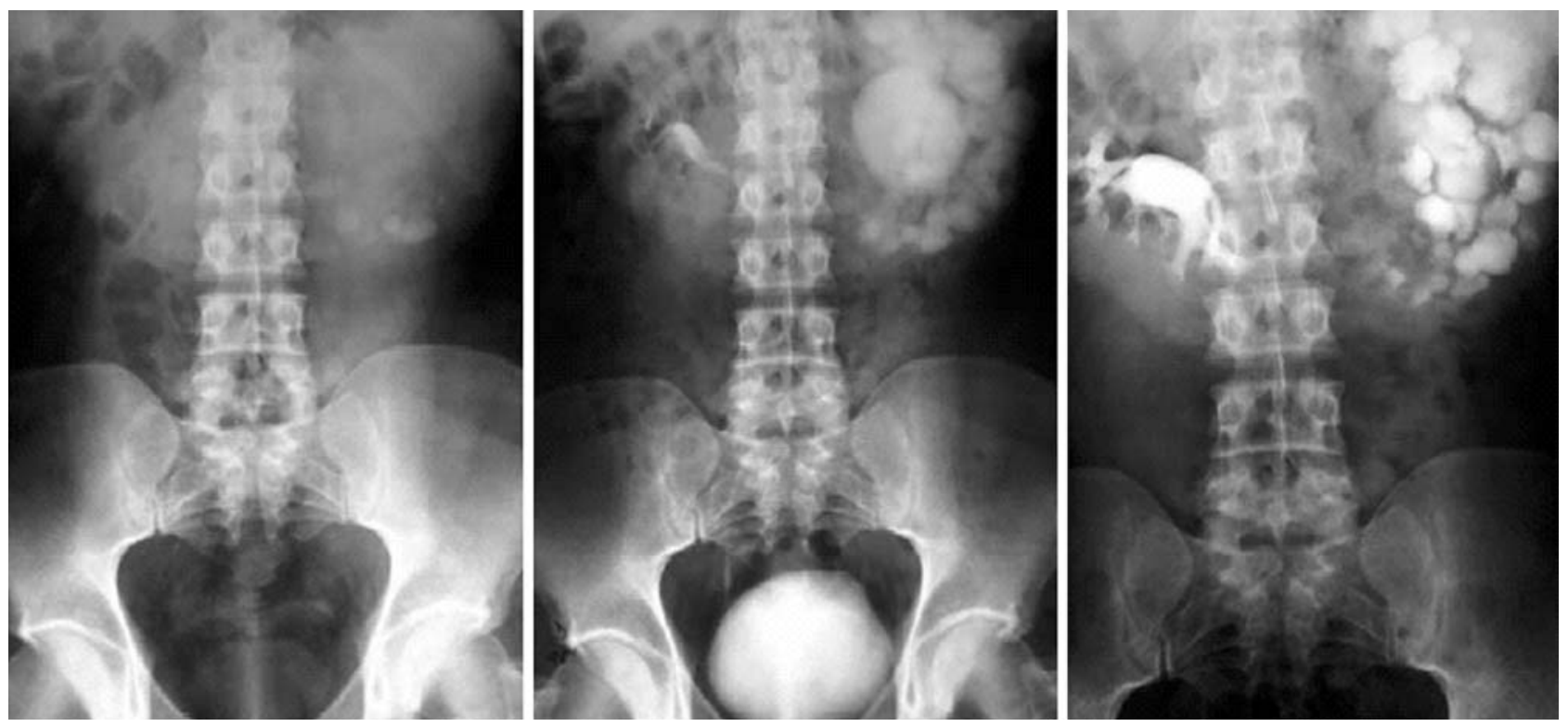

FIGURA 1 